\title{
The Relationship between Job Satisfaction and Organizational Commitment among Employees of a Selected Tertiary Educational Institution in Northwest Haiti
}

\author{
Willy Lima and Prof. Daniel Allida, Ph.D \\ Northern Caribbean University, Mandeville, Jamaica \\ Corresponding Author: wlima10@stu.ncu.edu.jm / lima.willy37@gmail.com
}

\begin{abstract}
This study sought to investigate the relationship between job satisfaction and organizational commitment among employees of a selected tertiary educational institution at Northwest of Haiti. A questionnaire was used to collect data from 55 employees. It was found that there is a moderate level of job satisfaction and high level of continuance and normative commitment among employees. It was also found that there is a strong positive relationship between job satisfaction and affective commitment and a weak positive relationship between job satisfaction and normative commitment. It was therefore recommended that administrators should seek to find ways and means to provide extrinsic and intrinsic motivating factors in order to prevent job dissatisfaction with regrettable consequences for the institution when employees may decide to leave their organization.
\end{abstract}

Keywords: Job Satisfaction, Commitment, affective, normative, continuance

\section{Introduction}

Teachers are the "central element in the educational system, holding various vital responsibilities" (Getahun, Tefera \&Burichew, 2016, p. 381). Teachers are the key players who ensure achievement of goals and objectives of the organization and they are key people who mold the students to excel toward their future career (Nigama, Selvabaskar \& Surulivel, 2018). According to Getahun, Tefera \& Burichew (2016), schools' overall performance depends upon teachers' level of commitment which can be affected by job satisfaction. They also mention that job satisfaction amongst teachers is a multifaceted construct imperative for the retention of teachers and is a significant determinant of teacher commitment and therefore a contributor to school effectiveness. Teachers would have excellent job performance when the organizational commitment is high (GuiXia, 2019).

Getahun, Tefera and Burichew (2016) found that teachers increasingly leave the profession after a few years in service. They further present the fact that worldwide studies have found that teachers are exposed to the highest level of job-related stress and are less satisfied with their jobs than any other professional group. They also pointed out that teacher's job satisfaction and commitment have been among the pressing educational issues. Lastly, they emphasized that job satisfaction is a crucial problem for all organizations whether public or private.

Research conducted by Aloi (2013) in Haiti found that there is a lack of workers' satisfaction whereby the workers are not really satisfied with the working conditions. Wolff (2008) declared that teachers in Haiti are not paid on time and some have not been paid over a year, the selection process is precarious, school directors play little or no significant role towards the teachers, and there are few sanctions and little oversight regarding the teachers. Carlson et al. (2011) stated that "it is tough to attract and retain qualified teachers within the existing structure, especially in the public sector, where teachers sometimes work for many months without receiving earned compensation" (p. 13).

Therefore, recruiting teachers and motivating them to remain in their jobs present a challenge to 
educational institutions in Haiti. Given the importance of workers' satisfaction to the health of an organization and the link between job satisfaction and turnover rate, the examination of job satisfaction at the selected tertiary education institution in Northwest Haiti becomes a vexing issue demanding attention. The primary focus of this study was therefore to determine the relationship between the level of job satisfaction and the level of organizational commitment of employees in the selected tertiary education institution in Northwest Haiti. The study sought to answer the following research questions:

1. What is the level job satisfaction of the employees of the selected tertiary institution in Northwest Haiti?

2. What is the level job commitment of the employees of the selected tertiary institution in Northwest Haiti?

3. Is there a significant relationship between levels of job satisfaction and organizational commitment of the employees of the selected tertiary institution in Northwest Haiti?

\section{Literature Review}

This section presents the concepts of Job Satisfaction, Organizational Commitment and the relationship between Job Satisfaction and Organizational Commitment.

\section{The Concept Job Satisfaction}

Job satisfaction is one of the most extensively researched areas in organizational literature because of its correlation to performance and productivity (UKEssays, 2018). According to Getahun, Tefera and Burichew (2016), job satisfaction of teachers has been a focus of attention for educational researchers; this is because of the prevailing link between job satisfaction and organizational behavior that might be explained in terms of commitment, absenteeism, turnover, efficiency and productivity. According to Morzaria (2019), job satisfaction plays a crucial role in the organization's well-being. This can be realized in an employee who sees his or her job as fulfilling and enjoyable, thus taking it with the importance deserved, unlike that employee who does not give his commitment since he or she feels dissatisfied.

According to Munir, Hashim, Ali, Rahman and Rahman (2014), job satisfaction has been defined differently by various scholars. According to Spector (2020), job satisfaction is the extent to which employees like their jobs and different aspects of their jobs. Employees can have an overall feeling about the job-bottom-line satisfaction or dissatisfaction. However, they do not necessarily feel the same about all aspects of the job. They might be happy with some parts of the job and not others.

\section{Organizational Commitment}

According to Akoto and Allida (2018) teachers' commitment is a critical aspect in determining the success of education reform and school effectiveness because highly committed teachers are willing to contribute their extra effort to achieve the school vision and goals. Further, organizational commitment is very important especially in this modern time when most teachers seek "greener pastures." As such, organizational commitment is the level of allegiance an employee feels for his employer (Donald, Lucia \& Victor, 2016). The authors further highlighted that employees with greater level of organizational commitment are more productive, compatible, have more loyalty towards their work, possess more responsibility and satisfaction.

There are three types of commitment namely, affective, normative and continuance. Affective commitment refers to employees' emotional connection to their employer, which generates a sense of belonging to, identification with and loyalty toward the organization. Employees who identify with their employer have a greater desire to remain in the organization (Lam \& Liu, 2014, as cited in Brown \& Barker, 2019). Normative commitment reflects employees' perceived moral obligation to stay with an organization, a willingness generated by a sense of duty and compulsion (Meyer \& Allen, 1997; Taing, Granger, Groff, Jackson \& Johnson, 2011, as cited in Brown \& Barker (2019). Continuance commitment emerges from employees' assessment of opportunities associated with remaining with an organization compared to the cost of leaving the employment (Meyer \& Allen, 1997; Brown \& Barker, 2019).

\section{Satisfaction and Commitment}

While job satisfaction is viewed as a pleasure or a positive emotional state resulting from the satisfactory evaluation of one's job or work experiences (Locke, 1976; Leung, Chen, Yu, 2008), commitment denotes an identification, an emotional attachment and an implication of the individual in the organization (Meyer et al., 2002). Researchers have found a healthy and positive 
relationship between the two (Asan \& Ozyer, 2008; Patrick \& Sonia, 2012).

Job satisfaction has been found to have a significant favorable influence on emotional engagement (Karatepe, Arasli, \& Khan, 2007; Newman \& Sheikh, 2012). According to Rifai (2005), job satisfaction has a significant impact on the development of emotional commitment through which it has a specific effect on the behavior of organizational citizenship. Thus, job satisfaction is a potent mediator in the relationship between employability and emotional organizational commitment (Yousaf \& Sanders, 2012).

Furthermore, emotional commitment and job satisfaction are both moderated by the perception of organizational support in their relationship to participation in decision-making (Wickramasinghe \& Wickramasinghe, 2012). Both contribute to lowering the level of intention to leave the organization (Anton, 2009; Cho and Huang, 2012; Karatepe et al., 2007; Pepe, 2010). They are both directly and positively influenced by psychological empowerment (Tolay et al., 2012) and negatively related to job insecurity (De Cuyper, Notelaers, \& De Witte, 2009). According to Clugston (2000), emotional commitment relates to the 'wish' of the employee because the employee's values and goals are congruent to the organization and there is a strong identification and attachment to the organization. So the scientific literature rightly admits that of the three dimensions of organizational commitment, affective commitment is the most strongly correlated with job satisfaction (Meyer, Stanley, Herscovitch \& Topolnytsky, 2002).

\section{Research Methodology}

This study employed a quantitative research approach using descriptive-correlational design. It sought to describe the levels of job satisfaction and organizational commitment of faculty of a selected tertiary education institution in Northwest, Haiti and also determined if there is a significant relationship between job satisfaction and organizational commitment.

\section{Population and Sampling}

The study was conducted in an educational institution in Haiti composed of mixed college reformers. The study respondents were fifty-five (55) employees of a selected tertiary education institutions in Northwest Haiti who participated in assessing the relationship between job satisfaction and organizational commitment among employees.
A purposive sampling technique was applied in the identification of the employees. All the 55 tertiary institution employees in Northwest Haiti participated in the study.

Two questionnaires were used to collect data for this study. Employees' level of job satisfaction was measured by adopting items from the Minnesota Satisfaction Questionnaire (MSQ20: the shortened version of MSQ which consisted of 20 items. The participants were asked to rate the extent to which they agreed with each items on a five point Likerttype scale ranging from very dissatisfied (1) to very satisfied (5). According to Martin (2007), the version of the MSQ used in this study has been used and validated by several researchers such as Eker et al., 2008; Holcomb-McCoy and Addison-Bradley, 2005; Robert, Young, and Kelly, 2006; Toomey et al., 2009). In addition, its reliability coefficients (i.e., internal consistency) varied between .87 and .92 (Holcomb-McCoy \& Addison-Bradley, 2005).

To measure the organizational commitment of the employees, the Organizational Commitment Questionnaire which measures the affective commitment scale, continuance commitment scale and normative commitment of the employees was used. The participants were asked to rate the extent to which they agreed with each items on a five point Likert- type scale ranging from Strongly Disagree (1) to Strongly Agree (5). Allen and Meyer (1991) report the alpha of 0.87 for affective commitment, 0.79 for normative and 0.75 for continuance.

\section{Findings of the Study}

This section presents the results of the study and gives the discussion of findings following the research questions that guided the study.

\section{The Level of Job Satisfaction of Employees}

The first research question in this study stated: what is the level job satisfaction of the employees of the selected tertiary institution in Northwest Haiti? Table 1 (p. 36) presents the result of data analysis about the level of job satisfaction of the respondents. Overall, it shows that employees were "Somewhat Satisfied" with their employment in their institution. Another important finding is that extrinsic satisfaction having the mean score of 2.48 (Somewhat satisfied) is much lower than intrinsic satisfaction with a mean score of 2.72 (Satisfied). It was also found that most of the items fell on the somewhat satisfied level of job satisfaction. There are only three items that belonged to satisfied as follows: the chance of being somebody in the 
community; the way the boss handles his/her workers; the competence of the supervisor in making decisions. The respondents indicated that they are not satisfied with their pay and the amount of work they do.

Studies on job satisfaction are very important because most of the people spend a major portion of their life at their working place. Moreover, job satisfaction has its impact on the general life of the employees because a satisfied employee is a contented and happy human being. For example, Lee and Tao (2005) found that satisfaction with the salary and the supervisor significantly increases emotional commitment. A highly satisfied worker has a better physical and mental well-being

Table 1: Level of Job Satisfaction of the Respondents

\begin{tabular}{lcl}
\hline \multicolumn{1}{c}{ Job Satisfaction Scale Items } & Mean & Interpretation \\
\hline Being able to keep busy all the time & 1.98 & Somewhat satisfied \\
The chance to work alone on the job & 2.07 & Somewhat satisfied \\
The chance to do different things from time to time & 1.98 & Somewhat satisfied \\
The chance to be "somebody" in the community & 2.85 & Satisfied \\
The way my boss handles his/her workers & 2.87 & Satisfied \\
The competence of my supervisor in making decisions & 3.04 & Satisfied \\
Being able to do things that don't go against my conscience & 2.20 & Somewhat satisfied \\
The way my job provides for steady employment & 2.14 & Somewhat satisfied \\
The chance to do things for other people & 2.31 & Somewhat satisfied \\
The chance to tell people what to do & 2.36 & Somewhat satisfied \\
The chance to do something that makes use of my abilities & 2.33 & Somewhat satisfied \\
The way company policies are put into practice & 1.54 & Somewhat satisfied \\
My pay and the amount of work I do & 1.34 & Not satisfied \\
The chances for advancement on this job & 2.45 & Somewhat satisfied \\
The freedom to use my own judgment & 2.40 & Somewhat satisfied \\
The chance to try my own methods of doing the job & 2.23 & Somewhat satisfied \\
The working conditions & 1.71 & Somewhat satisfied \\
The way my co-workers get along with each other & 2.31 & Somewhat satisfied \\
The praise I get for doing a good job & 2.29 & Somewhat satisfied \\
The feeling of accomplishment I get from the job & 2.29 & Somewhat satisfied \\
Total for Extrinsic Satisfaction & 2.48 & Somewhat Satisfied \\
Total for Intrinsic Satisfaction & 2.72 & Satisfied \\
Overall & 2.24 & Somewhat Satisfied \\
\hline
\end{tabular}

\section{The Level of Organizational Commitment}

The second research question stated: What is the level job commitment of the employees of the selected tertiary institution in Northwest Haiti? Table 2 (p. 37) shows the descriptive statistics for employees' commitment to their organization. Respondents agreed that they are committed to their institution. Comparing the three different areas of commitment, continuance commitment was rated the highest with the mean score of 4.26 followed by normative commitment with a mean score of 3.80 . The lowest mean score fell on affective commitment (3.01). Another interesting finding is that in the area of affective commitment, most of the respondents were undecided or not sure.

In continuance commitment, the employee is with the organization because disassociating with the organization would result in unbearable cost or loss of investments (Javadive \& Yavarian, 2012). It implies therefore that the respondents of this study were staying in the institution because there are just few better options available elsewhere where they could go to. Leaving the institution would therefore mean doing a personal sacrifice.

Normative commitment represents the employee's wish to stay within the organization because of the notion of duty, fidelity or moral obligation (Allen \& Meyer, 1991). Normative commitment is seen to be different from the other two commitments as employees may not be keen in relating to the values, missions and goals of the organization but to their own sense of loyalty and service that affects individual decision to stay within the organization (Clugston, 2000). The respondents agreed that they will feel guilty if they leave the organization by then. 
Also, they believed that they owe a great deal to the institution and that it deserves their loyalty.

Affective commitment refers to employees' emotional connection to their employer, which generates a sense of belonging to, identification with and loyalty toward the organization. Employees who identify with their employer have a greater desire to remain in the organization (Lam \& Liu, 2014, as cited in Brown \& Barker, 2019). The respondents were undecided when asked if they would be very happy to spend the rest of their career in their institution and also they are unsure if they have strong sense of belonging with their institution.

Table 2: Level of Organizational Commitment of the Respondents

\begin{tabular}{lcc}
\hline \multicolumn{1}{c}{ Items } & Mean & Interpretation \\
\hline I would be very happy to spend the rest of my career at the College. & 2.91 & Undecided \\
I really feel as if this organization's problems are my own & 2.60 & Undecided \\
I do not feel like "part of the family" at the College & 2.76 & Undecided \\
I do not feel "emotionally attached at the College & 3.40 & Undecided \\
Reform College has a great deal of personal meaning for me & 2.98 & Undecided \\
I do not feel a "strong" sense of belonging to the College & 3.42 & Undecided \\
It would be very hard for me to leave my job at this organization right now & 4.02 & Agree \\
Too much of my life would be disrupted if I leave my organization & 4.13 & Agree \\
Staying with my job at this organization is a matter of necessity as much as desire. & 4.27 & Agree \\
I believe I have too few options to consider leaving this organization. & 4.47 & Agree \\
Leaving this organization would be due to scarcity of alternatives elsewhere. & 4.25 & Agree \\
Leaving this organization would require considerable personal sacrifice. & 4.44 & Agree \\
I do not feel any obligation to remain with my organization & 2.49 & Slightly Agree \\
Even if it were to my advantage, I do not feel it would be right to leave. & 3.51 & Agree \\
I would feel guilty if I left this organization now. & 3.89 & Agree \\
This organization deserves my loyalty & 4.36 & Agree \\
I would not leave my organization right now because of my sense of obligation & 4.42 & Agree \\
I owe a great deal to this organization. & 4.49 & Agree \\
Affective Commitment Total & 3.01 & Agree \\
Continuance Commitment Total & 4.26 & Agree \\
Normative Commitment Total & 3.80 & Agree \\
Overall Commitment & $\mathbf{2 . 8 5}$ & Agree \\
\hline
\end{tabular}

Table 3: Relationship between Employees' Levels of Job Satisfaction and Organizational Commitment

\begin{tabular}{lllll}
\hline \multicolumn{1}{c}{$\begin{array}{c}\text { Organizational } \\
\text { Commitment }\end{array}$} & Total Satisfaction & Pearson $r$ & Sig value & Interpretation \\
\hline Affective commitment & & & \\
Continuance commitment & .671 & .000 & Significantly Related \\
Normative commitment &. .089 & .519 & No Significant Relationship \\
Total Commitment & .324 & .016 & Significantly Related \\
\hline
\end{tabular}

\section{Satisfaction and Commitment}

Research question 3 asked if there a significant relationship between levels of job satisfaction and organizational commitment of the employees within the selected tertiary institution in Northwest Haiti.

Table 3 showed that there is a strong positive relationship between satisfaction and affective commitment $[r=.671, p=.000)$ showing that with an increase in satisfaction there is an increase in commitment. Also, there was a weak positive relationship between normative commitment and satisfaction $[r=.324, n=55, p=.016]$. It was also found that total satisfaction is significantly related with normative commitment $(r=.324, p=.004)$. The result of this study showed that the higher the job satisfaction of the employees, the greater will be their affective and normative commitment. In summary, total satisfaction is significantly related to overall commitment.

So, it is with good reason that the scientific literature admits that of the three dimensions of organizational engagement, affective (emotional) engagement is the most strongly correlated with job satisfaction (Meyer et al., 2002). Allen and Meyer (2000) argue that organizational commitment is a psychological phenomenon regarding the 
relationship of the employee with the organization and this may decrease the employee intention to leave the organization. According to Rifai (2005), job satisfaction has a significant impact on the development of emotional commitment through which it has a specific effect on the behavior of organizational citizenship.

\section{Conclusion and Recommendations}

This section presents the conclusions of the study and then gives the recommendations.

\section{Conclusions}

The study concludes that the employees of the selected tertiary education institution have moderate level of job satisfaction. They are more satisfied by the intrinsic factors rather than the extrinsic ones and they are committed to the organization. However, the main reason they stay is because they believed that they are indebted a lot from their organization and therefore they need to be loyal to it. Lastly, it was found that both affective and normative commitment are significantly related to organizational commitment. This shows that the higher the job satisfaction of the employees, the more committed they become.

\section{Recommendations}

Since this study found that there is a significant correlation between job satisfaction and organizational commitment, it is relevant that administrators should look on the avenues to increase job satisfaction levels of their employees. There is a need to focus on factors affecting the extrinsic and intrinsic motivations of the employees so that stronger commitment and greater loyalty may be demonstrated by the teachers.

\section{Reference}

Akoto, M.A \& Allida, D. (2018). Relationship of School Climate and Organizational Teacher's Commitment. International Book Market Service Ltd, Scholar's Press

Allen, N. J. et Meyer, J. P. (1991). The measurement and antecedents of affective, continuance and normative commitment to the organization. Journal of Occupational Psychology, 63(1), 1-18. doi $: 10.1111 /$ j.2044-8325. 1990.tb00506.x

Allen, N. J., \& Meyer, J. P. (2000). Construct validation in organizational behavior research: The case of organizational commitment Problems and Solutions in Human Assessment. NY: Springer.

Aloi, D. (2013). Haitian student studies job satisfaction as poverty solution. (Masteral thesis), Cornell University. Retrieved from https://news.cornell.edu/stories/2013/08/h aitian-student-looks-solve-poverty-jobsatisfaction

Anton, C. (2009). The impact of role stress on workers 'behavior through job satisfaction and organizational commitment. International Journal of Psychology: International Journal of Psychology, 44 (3), 187-194. doi: 10.1080 / 00207590701 700511.

Asan, O. et Ozyer, K. (2008). An empirical study on the analysis of the relationship between affective commitment and job satisfaction and sub dimensions of job satisfaction. The Journal of Faculty of Economics \& Administrative Sciences, 13(3), 129-151.

Brown, T., Barker, G.G. (2019). The Relationship Between Job Satisfaction and Organizational Commitment: A Small Business Perspective. Advances in Business Research, 9(1), 112130. Retrieved from https://journals.sfu.ca/abr/.

Carlson, W.L., Désir, A., Goetz, S., Hong, S., Jones, S. \& White, J. (2011). The Haitian Diaspora and education reform in Haiti: Challenges and recommendations. Columbia university school of international and public affairs. Retrieved from https://www.haitinow.org/wp-content/uploads/2017 /05 /Education-Reform-in-Haiti-ChallengesRecommendations-Columbia-May-2011.pdf

Cho, V. and Huang, X. (2012). Professional commitment, organizational commitment, and the intention to leave for professional advancement: An empirical study on IT professionals. Information Technology \& People, 25 (1), 31-54. doi: 10.1108 / 09593841211204335

Clugston, M. (2000). The mediating effects of multidimensional commitment on job satisfaction and intent to leave. Journal of Organizational Behaviour, 21, 477-486

De Cuyper, N., Notelaers, G. \& De Witte, H. (2009). Job insecurity and employability in fixed- 
term contractors, agency workers, and permanent workers: Associations with job satisfaction and affective commitment. Journal of Occupational Health Psychology, 14(2), 193-205. doi:10.1037/a0014603

Donald, M.F., Lucia, M.E., Victor, N.M. (2016). The Relationship between Job Satisfaction and Organizational Commitment among Academic Staff Members in a Selected Higher Education Institution. The 2016 WEI International Academic Conference Proceedings, 38-47. Retrieved from https://www.westeastinstitute.com/wpcontent/uploads/2016/05/FumaniMabasa_2.pdf

Eker, M., Eker, S. \& Pala, F. (2008). The effects of job satisfaction on organizational commitment among Turkish health care staff: An empirical study. Journal of Academic Studies, 10(36), 46-68.

Getahun, T., Tefera, B.F. \& Burichew, A.H. (2016). Teacher's Job Satisfaction and Its Relationship with Organizational Commitment in Ethiopian Primary Schools: Focus On Primary Schools of Bonga Town. European Scientific Journal, 12 (13), 380401. doi: 10.19044/esj. 2016.v12n13p380

GuiXia, W., Basri, R., \& Jusoh, R. (2019). The Relationship between Job Satisfaction and Organizational Commitment among Lecturers in Heilongjiang Province, China. International Journal of Academic Research in Business and Social Sciences, 9(11), 99118. DOI: $10.6007 /$ IJARBSS/v9-i11/6533

Holcomb-McCoy, C. \& Addison-Bradley, C. (2005). African American counselor educators' job satisfaction and perceptions of departmental racial climate. Counselor Education \& Supervision, 45, 2-15.

Javadi, M. H. M. \& Yavarian, J. (2012). Effect of organizational identity and commitment on organizational citizenship behaviour (Case study: Educational department of Isfahan province). Interdisciplinary Journal of Contemporary Research in Business, 3(2), 100- 112.

Karatepe, O. M., Arasli, H. et Khan, A. (2007). The impact of self-efficacy on job outcomes of hotel employees: Evidence from Northern
Cyprus. International Journal of Hospitality \& Tourism Administration, 8(4), 23-46.

Lee, K. S. et Tao, G. (2005). Studying organizational commitment with the OCQ in the Korean retail context: Its dimensionality and relationships with satisfaction and work outcomes. International Review of Retail, Distribution \& Consumer Research, 15(4), 375-399. doi:10.1111/1464-0597.00075

Leung, M. Y., Chen, D. \& Yu, J. (2008). Demystify the moderate variables of the interrelationships between affective commitment, job performance and job satisfaction of construction professionals. Journal of Construction Engineering \& Management, 134 (12), 963-971. doi: 10.1061.

Locke, E.A. (1976) The Nature and Causes of Job Satisfaction. In: Dunnette, M.D., Ed., Handbook of Industrial and Organizational Psychology, Vol. 1, 1297-1343.

Martin, A. (2007). Perceptions of Organizational Commitment, Job Satisfaction and Turnover Intentions in a Post-Merger South African Tertiary. University of Johannesburg.

Meyer, J.P., Stanley, D.J., Herscovitch, L. \& Topolnytsky, L. (2002). Affective, Continuance, and Normative Commitment to the Organization: A Meta-analysis of Antecedents, Correlates, and Consequences. Journal of Vocational Behavior 61(1), 20-52. DOI: 10.1006/jvbe.2001.1842.

Meyer, J. P., \& Allen, N. J. (1997). Advanced topics in organization behavior series. Commitment in the workplace: Theory, research, and application. Sage Publications, Inc.

Morzaria, H. (2019). The Crucial Role of Job Satisfaction. Retrieved from https://www.business2community.com/hu man-resources/the-crucial-role-of-jobsatisfaction-02267769

Munir, R.I.S, Hashim, N., Ali, S.A.M, Rahman, B.A., Rahman, R.A. (2014). Relationship between Job Satisfaction and Organizational Commitment at Health Tourism Hospital in Malaysia Knowledge Management International Conference (KMICe) 2014, 12 - $15 . \quad$ Retrieved from https://www.researchgate.net/publication/ 
319881944_Relationship_between_Job_Sati sfaction_and_Organizational_Commitment_ at_Health_Tourism_Hospital_in_Malaysia

Newman, A. et Sheikh, A. Z. (2012). Organizational rewards and employee commitment: A Chinese study. Journal of Managerial Psychology, 27(1), 71-89. doi:10.1108/02683941211193866

Nigama, K., Selvabaskar, S., Surulivel, S.T. (2018). Job satisfaction among school teachers. International Journal of Pure and Applied Mathematics, 119(7), 2645-2655

Patrick, H. A. and Sonia, J. (2012). Job satisfaction and affective commitment. The IUP Journal of Organizational Behavior, 11 (1), 23-36.

Pepe, M. (2010). The impact of extrinsic motivational dissatisfiers on employee level of job satisfaction and commitment resulting in the intent to turnover. Journal

of Business \& Economics Research, 8(9), 99107.

Rifai, H. A. (2005). A test of the relationships among perceptions of justice, job satisfaction, affective commitment, and organizational citizenship behavior. Gadjah Mada International Journal of Business, 7(2), 131154.

Robert, T. E., Young, J. S. et Kelly, V. A. (2006). Relationship between adults' workers' spiritual well-being and job satisfaction: $A$ preliminary study. Counseling and Values, 50, 165-175.

Spector, P.E. (2020). Here's How to Measure Employee Job Satisfaction. Retrieved from http://paulspector.com/organizationalbehavior/heres-how-to-measure-employeejob-satisfaction/
Tolay, E., Surgevil, O. et Topoyan, M. (2012). Impact of structural and psychological empowerment on affective commitment and job satisfaction in academic work settings. Ege Academic Review, 12(4), 449465.

Toomey, K. D., Levinson, E. M. et Palmer, E. J. (2009). A test of Holland's theory of vocational personalities and work environments. Journal of Employment Counseling, 46, 82-93.

UKEssays. (2018). Impact of Job Satisfaction on Workplace Employees. Retrieved from https://www.ukessays.com/essays/employ ment/impact-of-job-satisfaction-onworkplace-employees. php?vref=1

Wickramasinghe, D. et Wickramasinghe, V. (2012). Effects of perceived organizational support on participation in decision making, affective commitment, and job satisfaction in lean production in Sri Lanka. Journal of Manufacturing Technology Management, 23(2), 157-177. doi:10.1108/17410381211202179

Wolff, L. (2008). Education in Haiti: The Way Forward. Washington, DC: PREAL. As of May 23, 2012 (PREAL),1-20. Retrieved fromhttp://archive.thedialogue.org/Publicat ionFiles/Education\%20in\%20Haiti\%20\%20The\%20Way\%20Forward\%20\%20FINAL\%20-\%209-15-08.pdf

Yousaf, A. et Sanders, K. (2012). The role of job satisfaction and self-efficacy as mediating mechanisms in the employability and affective organizational commitment relationship: A case from a Pakistani university. Thunderbird International Business Review, 54(6), 907-919. Doi $: 10.1002 /$ tie.21511 